\title{
EFEK KEPEMILIKAN INSTITUSIONAL, PROFITABILITAS, UKURAN PERUSAHAAN DAN PERTUMBUHAN PENJUALAN TERHADAP NILAI PERUSAHAAN DENGAN STRUKTUR MODAL SEBAGAI VARIABEL INTERVENING
}

(Studi Pada Perusahaan Manufaktur di BEI Tahun 2013-2017)

Tagora Bangkit Pahala Simanjuntak ${ }^{1}$, Irene Rini Demi Pangestuti²

${ }^{1}$ Magister Manajemen, Fakultas Ekonomika dan Bisnis, Universitas Diponegoro

${ }^{2}$ Magister Manajemen, Fakultas Ekonomika dan Bisnis, Universitas Diponegoro

\begin{abstract}
ABSTRAK
Tujuan penelitian ini adalah untuk menguji pengaruh kepemilikan insitutisional, profitabilitas, ukuran perusahaan dan pertumbuhan penjualan terhadap nilai perusahaan dengan struktur modal sebagai variabel intervening (studi di Perusahaan Manufaktur Listing di Bursa Efek Indonesia sejak 2013 sampai periode 2017). Sampel dalam penelitian ini adalah perusahaan manufaktur sesuai dengan kriteria yang ditetapkan. Analisis regresi linear berganda dilakukan dengan didasarkan pada hasil analisis data. Penelitian ini menyimpulkan beberapa hal sebagai berikut: Variabel kepemilikan institusional, profitabilitas dan ukuran perusahaan berpengaruh negatif signifikan terhadap struktur modal. Pertumbuhan penjualan tidak berpengaruh terhadap struktur modal. Kepemilikan institusional tidak berpengaruh terhadap nilai perusahaan. Profitabilitas, ukuran perusahaan dan pertumbuhan penjualan berpengaruh positif signifikan terhadap nilai perusahaan. Struktur modal berpengaruh negatif signifikan terhadap nilai perusahaan. Struktur modal dapat memediasi pengaruh kepemilikan institusional, profitabilitas dan ukuran perusahaan terhadap nilai perusahaan. Struktur modal tidak dapat memediasi pengaruh pertumbuhan penjualan terhadap nilai perusahaan..
\end{abstract}

Kata Kunci: kepemilikan institusional, profitabilitas, ukuran perusahaan, pertumbuhan penjualan, struktur modal, nilai perusahaan

\section{PENDAHULUAN}

Dalam perkembangannya, suatu perusahaan memiliki tujuan memaksimalkan nilai perusahaan. Nilai perusahaan yang semakin tinggi membuat investor lebih yakin untuk berinvestasi pada perusahaan dikarenakan perusahaan memiliki prospek yang bagus (Salvatore, 2005). Perusahaan dengan nilai perusahaan yang tinggi erat kaitannya dengan persepsi investor mengenai tingkatan dari perusahaan yang sukses. Nilai perusahaan yang tinggi mengakibatkan investor memperoleh return yang tinggi dari nilai investasi yang dia korbankan apabila nilai perusahaan mampu dioptimalkan oleh manajemen perusahaan (Hermuningsih, 2013). Karena para investor akan melihat pertumbuhan perusahaan dan juga melihat seberapa tinggi nilai perusahaan sebelum

${ }^{1}$ Corresponding author, Email: tagorasimanjuntak@gmail.com 
investor menginvestasikan dananya. Manajer harus mampu menciptakan sinyal positif untuk memaksimalkan nilai perusahaan, dikarenakan suatu keputusan keuangan memiliki pengaruh terhadap keputusan keuangan lainnya dan ini juga berpengaruh terhadap firm value.

Penelitian ini berfokus pada faktor yang dipandang dapat dikontrol oleh perusahaan yaitu faktor internal merupakan faktor esensial yang dapat memberi pengaruh dalam menentukan harga saham. Dalam suatu analisis pasar modal, faktor internal suatu perusahaan indentik dengan fundamental keuangan. Faktor ini yang dapat dikontrol dalam pengendalian perusahaan. Sebuah perusahaan biasanya mengeluarkan laporan keuangan baik dalam tahunan maupun semesteran yang mempunyai pengaruh signifikan terhadap firm value. Pencapaian firm value yang maksimal dapat dicapai pada laporan keuangan yang baik menunjukkan rasio keuangan perusahaan yang baik.

Penelitian ini bertujuan untuk menganalisis pengaruh kepemilikan institusional, profitabilitas, ukuran perusahan dan pertumbuhan penjualan terhadap firm value dengan struktur modal sebagai variabel intervening. Penelitian ini diharapkan memberikan manfaat teoritis berupa sumbangsih informasi dan pengetahuan mengenai materi-materi terkait serta diharapkan memberikan hasil yang dapat digunakan sebagai gambaran bagi manajemen perusahaan.

\section{TELAAH PUSTAKA Teori Agensi}

Teori agensi menekankan pada adanya perbedaan kepentingan antara pemilik perusahaan sebagai principal yang ingin memiliki resiko seminimal mungkin, dan dewan direksi sebagai agent yang ingin mendapatkan penilaian yang baik. Keadaan asimetri menyebabkan informasi yang diterima 2 pihak yakni manajemen dan principal memiliki perbedaan distribusi informasi antara principal dan agent. Sulitnya pihak pemilik dalam mengendalikan dan melakukan pengawasan sebagai sarana kontrol karena berada di pihak eksternal perusahaan tehadap agent menjadi penyebab asimetri informasi terkait / penyebab konflik keagenan (Amanda Wongso, 2012).

\section{Teori Pecking Order}

Pecking order theory menjelaskan suatu perusahaan pada umumnya lebih memprioritaskan sumber pembiayaan internal kemudian hutang dan pilihan terakhir yaitu pembiayaan ekuitas, teori pecking order mengikuti hierarki pembiayaan untuk meminimalkan informasi asimetri antar pihak (Myers dan Majlup, 1984).

\section{Teori Balancing (Trade of Theory)}

Teori ini menjelaskan berapa jumlah sumber pendanaan berbentuk hutang yang harus digunakan oleh perusahaan dengan mempertimbangkan manfaat serta beban biaya yang dihasilkan dari penerbitan hutang dalam komposisi struktur modal. Baker \& Martin (2011) memaparkan bahwa manfaat yang didapatkan oleh perusahaan ketika menggunakan hutang adalah penghematan pajak, hal tersebut disebabkan oleh beban bunga dari hutang mampu mengurangi pajak yang harus ditanggung perusahaan. Biaya yang ditimbulkan dari penggunaan hutang adalah bunga, meskipun beban bunga mampu mengurangi pajak yang harus ditanggung oleh perusahaan menurut Hanafi (2014) berdasarkan fakta bahwa tidak mungkin keseluruhan investasi yang dilakukan oleh perusahaan dibiayai oleh hutang. Hal tersebut dikarenakan semakin tinggi hutang perusahaan, maka potensi kerugian atau 
resiko dalam hal ini kebangkrutan perusahaan juga meningkat.

\section{Teori Sinyal}

Sebuah perusahaan memberikan sinyal baik atau sinyal buruk yang diterima oleh investor merupakan tujuan dari teori sinyal. Penyampaian financial statement merupakan informasi publikasi untuk menyampaikan sinyal mengenai kontrak yang disepakati bersama antara agen dan manajer telah sesuai dengan kesepakatan. Informasi asimetri menurut Brightman dan Houston (1999) yaitu manajer lebih mengetahui kondisi perusahaan serta prospek perusahaan daripada investor. Menurut Amanda Wongso (2012) dasar dari teori signalling adalah adanya asimetri informasi antara investor dan manajemen. Informasi tersebut yang akan menjadi pembeda entitas yang memiliki kualitas baik dan entitas yang memiliki kualitas kurang baik.

\section{Nilai Perusahaan}

Hubungan rasio PBV terhadap kepercayaan pasar yaitu hubungan positif dimana PBV yang tinggi mengindikasikan bahwa semakin percayanya pasar terhadap prospek perusahaan tersebut. Membeli saham perusahaan berindikasi bahwa investor yakin akan prospek perusahaan. Rasio PBV mengindikasikan nilai perusahaan yang terus tumbuh. Semakin meningkatnya price to book value berindikasi prospek perusahaan pada masa yang akan datang sangat baik. Nilai perusahaan yang tinggi berhubungan linear terhadap meningkatnya juga kemakmuran pemegang saham.

\section{Struktur Modal}

Dalam sistem permodalan perusahaan memiliki susunan atau struktur yang disebut dengan struktur modal di mana struktur modal merupakan metode pilihan komposisi modal perusahaan antara modal yang diperoleh yang berasal dari modal internal dan yang bersumber dari modal hutang. Rasio ini menunjukkan tinggi rendahnya resiko yang dialami perusahaan karena besar kecilnya pilihan komposisi modal berupa hutang. Ketika rasio struktur modal ini meningkat menunjukkan bahwa proporsi penggunaan hutang sebagai sumber pendanaan lebih besar dalam menjalankan aktivitas perusahaan guna meningkatkan pendapatan laba (Kesuma, 2009).

\section{Kepemilikan Institusional}

Perusahaan, institusi dan lembaga lainnya yang memiliki sebagian saham perusahaan dinamakan kepemilikan institusi. Kepemilikan institusi berguna dalam pengendalian dan pengawasan manajer agar aktivitas perusahaan dapat berjalan untuk memaksimalkan kesejahteraan dan kemakmuran pemegang saham (Amanda Wongso, 2012). Kepemilikan institusi/perusahaan dapat berupa perusahaan yang masih menjadi satu group maupun perusahaan lain yang berpartisipasi dalam pengambilan keputusan perusahaan. Hasnawati dan Sawir (2015) kembali mengungkapkan bahwa kepemilikan institusi sebagai agen pengendali memiliki peranan konsisten dan aktif mekanisme pembagian wewenang, kekuasaan dan keuntungan guna memakmurkan pemegang saham.

\section{Profitabilitas}

Profitabilitas menunjukkan seberapa baik manajemen dapat memanfaatkan total aset produktif untuk menghasilkan laba perusahaan. Rasio profitabilitas dapat diidentikan antara gabungan dari rasio liqudity, asset management, dan debt management. Salah satu penilaian dasar dari kondisi perusahaan adalah dengan rasio profitabilitas. 


\section{Ukuran Perusahaan}

Nilai yang seringkali digunakan untuk melakukan pengelompokan suatu perusahaan besar atau kecil dengan ukuran perusahaan. Investor di bursa sering beranggapan bahwa menanam saham di perusahaan besar lebih meyakinkan dan dapat mendatangkan keuntungan yang lebih maksimal daripada menanam saham di perusahaan dengan ukuran kecil selain itu pada penyajian laporan keuangan disclosure akan muncul lebih banyak pengungkapan yang informatif di mana sangat dibutuhkan oleh investor dalam mengambil keputusan investasi. Selain itu berguna dalam posisi tawar sehingga dapat menentukan nilai kontrak (Hasnawati dan Sawir, 2015).

\section{Pertumbuhan Penjualan}

Perusahaan dengan pertumbuhan yang tinggi dapat menghasilkan net income lebih besar yang berkorelasi pada ketersediaan pendanaan dari internal. Hal ini dapat menguntungkan perusahaan karena dapat memperkecil rasio struktur modal. Pengukuran tingkat pertumbuhan penjualan dapat diukur dari pertumbuhan laba (Pritarini, 2011).

\section{Kerangka Pemikiran Teoritis Dan Perumusan Hipotesis \\ Pengaruh kepemilikan institusional terhadap capital structure}

Kepemilikan saham yang didominasi oleh institusional banyak ditemukan dalam perusahaan yang sudah IPO. Kendali perusahaan secara keseluruhan tentunya berada pada pemilik institusi tersebut. Keputusan pendanaan umumnya menjadi keputusan yang sensitif dalam menentukan komposisi struktur modal perusahaan. Teori agensi dimana saham pihak institusional yang besar memberikan pengaruh terhadap konflik keagenan semakin kecil dimana pihak institusional melakukan pengawasan yang ketat terhadap kebijakan yang dilakukan manajemen mengenai struktur modal. Dengan adanya pengawasan oleh pihak institusional memiliki pengaruh manajer lebih alert dalam membuat keputusan kebijakan pendanaan, sehingga hutang yang digunakan dapat ditekan seminimal mungkin (Jensen dkk, 1992). Hipotesis ini didukung oleh penelitian Chune Young Chung dan Kainan Wang (2018). H1: Institutional ownership berpengaruh negatif terhadap DER

\section{Pengaruh profitabilitas terhadap capital structure}

Struktur modal perusahaan dapat dipengaruhi oleh profitabilitas. Perusahaan dengan tingkat keuntungan yang tinggi dapat dengan mudah menutup hutang-hutang jangka pendek. Tentunya perusahaan akan mengurangi pendanaan yang bersumber dari ekternal (hutang) dengan laba ditahan yang diperoleh perusahaan agar lebih efisien dan efektif. Pecking order theory memaparkan perusahaan memprioritaskan pemakaian sumber daya internal sebagai sumber pendanaan perusahaan dibandingkan memutuskan berhutang. Sehingga dapat disimpulkan hubungan negatif yaitu profitabilitas yang meningkat maka struktur modalnya semakin kecil (Sigita Lestari, 2015).

Hipotesis ini didukung oleh Purwohandoko (2017); Basil Al Najjar dan Khaled Husainney (2011); Nadeem Ahmed Sheikh dan Zongjun Wang (2013); Rajni Sofat dan Sukhdev Singh (2017); Ramazan Yildirima, dkk (2018); Larry Li dan Silvia Z (2018); Tharmalingam Pratheepan dan Y.K.Weerakoon Banda (2016); Mohammad Alipour, dkk (2017).

H2: Profitability berpengaruh negatif terhadap capital structure 
Pengaruh firm size terhadap capital structure

Sesuai teori pecking order perusahaan berukuran besar lebih memprioritaskan penggunaan sumber dana internal (ekuitas) untuk membiayai operasionalnya daripada menggunakan sumber dana eksternal. Perusahaan besar identik mempunyai total aset besar berpeluang untuk menghasilkan pendapatan yang besar sehingga akan cenderung menggunakan laba perusahaan untuk diinvestasikan kembali. Perusahaan besar akan membutuhkan lebih sedikit dana eksternal berupa hutang dari pada perusahaan kecil. Hipotesis ini didukung oleh Elva Nuraina (2012); Mohammad Alipour, dkk (2017).

H3: Firm size berpengaruh negatif terhadap capital structure

\section{Pengaruh growth sales terhadap capital structure}

Tingkat pertumbuhan perusahaan yang tinggi mengindikasikan bahwa aktivitas penjualan perusahaan yang dilakukan meningkat dari periode sebelumnya, dengan semakin meningkatnya pertumbuhan penjualan berdampak terhadap meningkatnya laba perusahaan yang dihasilkan, dengan peningkatan laba yang dihasilkan berpengaruh pada peningkatan kas perusahaan periode mendatang, membuat penggunaan hutang dalam hal ini semakin berkurang sesuai terhadap teori pecking order (Saidi, 2002). Hipotesis ini didukung oleh Mohammad Javad Shyekh, dkk (2017); Mohammad Alipour, dkk (2017).

H4: Growth sales berpengaruh negatif terhadap capital structure

\section{Pengaruh kepemilikan institusional terhadap firm value}

Agen fungsi monitoring yang dijalankan oleh pemegang saham institusi hanya dimiliki oleh perusahaan dengan kepemilikan saham yang dominan. Pengambilan keputusan akan lebih hati-hati diambil oleh para manajer. Semakin tinggi kepemilikan institusi sebuah perusahaan berarti pengendalian semakin tinggi, investor akan makin percaya. Hal inilah yang menjadikan nilai perusahaan meningkat. Jensen dan Meckling (1976) dengan teori agency menjelaskan kepemilikan oleh pihak institusi dapat mengurangi konflik keagenan seperti perilaku oportunistik manajer, mencegah manajemen laba dan mengurangi biaya keagenan. Hipotesis ini didukung oleh Ngatemin, dkk (2018); Johny Budiman (2015); Elva Nuraina (2012); Rakesh Mishra dan Sheeba Kapil (2017); Yongjia Rebecca Lin dan Xiaoqing Maggie Fu (2017).

H5: Institutional ownership berpengaruh positif terhadap firm value

Pengaruh profitability terhadap firm value Suatu perusahaan yang mampu memproduksi laba yang tinggi menyebarkan sinyal positif pada investor. Bahwasannya tingkat keuntungan yang tinggi menunjukkan kemampuan perusahaan memperoleh keuntungan dengan mengalokasikan semua pos asset yang dimilikinya pada akun yang seharusnya. Profit perusahaan nantinya akan mampu mengestimasikan berapa besar keuntungan yang didapatkan oleh investor apabila menanamkan modal pada perusahaan tersebut. Hipotesis ini didukung Ngatemin, dkk (2018); Muhammad Thamrin, H. Rahman Mus, Sudirman dan Aryati Arfah (2017); Ayu Sri dan Ary Wirajaya (2013); Aldea Mita Cheryta, Moeljadi dan Nur Khusniyah Indrawati (2017); Yuanita Missy, Budiyanto dan Slamet Riyadi (2016); Ben Said Hatem (2015); Divya Anngarwal dan Purna Chandra Padhan (2017); Hariandy Hasbi (2015). H6: Profitabilitas berpengaruh positif terhadap firm value 
Pengaruh firm size terhadap firm value

Investor lebih senang menginvestasikan dananya pada perusahaan besar, dikarenakan perusahaan besar mempunyai kondisi keuangan yang stabil. Semakin besar perusahaan pada umumnya lebih dikenal oleh publik daripada perusahaan kecil, sehingga informasi dapat dengan mudah diperoleh yang berdampak meningkatkan nilai saham perusahaan. Hal ini sesuai dengan signaling theory perusahaan yang mempunyai firm size besar menunjukkan perusahaan sudah mencapai dalam tahap yang dewasa, dalam tahap arus kas positif dan dapat bertahan jangka waktu yang lama, dan dengan ukuran perusahaan yang besar berindikasi bahwa perusahaan relatif stabil dibandingkan dengan ukuran perusahaan yang kecil (Siahaan, 2013). Hipotesis ini didukung oleh Ben Said Hatem (2015); Yuanita Missy, Budiyanto dan Slamet Riyadi (2016) dan Siahaan (2013) ; Elva Nuraina (2012); Nadeem Ahmed Sheikh dan Zongjun Wang (2013) ; Divya Anngarwal dan Purna Chandra Padhan (2017).

H7: Firm size berpengaruh positif terhadap firm value

Pengaruh growth sales terhadap firm value Sesuai signaling theory investor akan yakin menanamkan dana yang dimiliki pada perusahaan yang memiliki pertumbuhan penjualan besar sehingga diharapkan akan memberikan return yang lebih besar apabila sejalan dengan efisiensi operasional perusahaan. Hipotesis ini didukung oleh Nadeem Ahmed Sheikh dan Zongjun Wang (2013); Thi Phuong Vy Le dan Thi Bich Nguyet Phan (2017).

H8: Growth sales berpengaruh positif terhadap firm value

Pengaruh capital structure terhadap firm value
Brigham dan Houston (2010) menjelaskan hubungan antara struktur modal dan nilai perusahaan melaluhi teori trade off. Teori tersebut menyebutkan bahwa manfaat pajak melaluhi pembiayaan hutang lebih diutamakan oleh perusahaan. Jika pengurang pembayaran pajak (biaya yang dikurangkan dari pajak) dengan biaya bunga hutang maka nilai perusahaan meningkat dengan adanya penggunaan hutang (Modigliani-Miller, 1963).

Di sisi lain, trade off theory menjelaskan nilai perusahaan meningkat pada penerbitan hutang tambahan pada saat posisi struktur modal berada di bawah titik optimal. Sebaliknya, hutang tambahan apa pun akan menurunkan nilai perusahaan pada kondisi masing-masing struktur modal berada di atas titik optimal. Dapat dikatakan bahwa struktur modal memiliki pengaruh pada nilai perusahaan.

Hipotesis ini didukung oleh Nadeem Ahmed Sheikh dan Zongjun Wang (2013); Ayu Sri Mahatma Dewi dan Ary Wirajaya (2013); Siahaan (2013); Rakesh Mishra dan Sheeba Kapil (2017); Thi Phuong Vy Le dan Thi Bich Nguyet Phan (2017); Asifa Kausar, dkk (2014).

H9: Capital structure berpengaruh negatif terhadap firm value

Efek mediasi capital structure pada pengaruh institutional ownership terhadap firm value

Teori agensi dimana saham pihak institusional yang besar maka konflik keagenan dapat diturunkan dengan melakukan pengawasan agen terkait kebijakan manajemen struktur modal. Dengan pengawasan yang dilakukan pihak institusional maka manajer akan lebih prudensial pada setiap kebijakannya terutama kebijakan hutang, sehingga penerbitan hutang yang dilakukan menjadi rendah (Jensen dkk, 1992). Hal ini 
dikarenakan kepemilikan institusional memiliki tujuan lebih besar dari sekedar mencapai tujuan perusahaan saja. Peningkatan hutang perusahaan memiliki sinyal negatif kepada investor. Struktur modal dapat menurunkan nilai perusahaan menunjukkan sinyal negatif (Ang, 1997). Hipotesis ini didukung oleh Johny Budiman (2015).

H10: Struktur modal diduga mampu memediasi pengaruh institutional ownership terhadap firm value.

Efek mediasi capital structure pada pengaruh profitability terhadap firm value Peningkatan profitabilitas memiliki pengaruh positif pada perusahaan yaitu perusahaan dapat membiayai investasi maupun operasional perusahaan yang berasal dari dana internal, yang mempengaruhi tingkat leverage perusahaan yang kecil, yang diduga berpengaruh positif terhadap nilai perusahaan dan berdampak terhadap investor yang ingin membeli saham dengan profitabilitas yang tinggi. Hipotesis ini didukung oleh Johny Budiman (2015); Sri Hermuningsih (2012).

H11: Capital structure diduga mampu memediasi pengaruh profitability terhadap firm value

\section{Efek mediasi capital structure pada firm size terhadap firm value}

Perusahaan besar berpeluang untuk menghasilkan pendapatan yang besar sehingga akan cenderung menggunakan laba perusahaan untuk diinvestasikan kembali. Perusahaan besar akan membutuhkan lebih sedikit dana eksternal berupa hutang dari pada perusahaan kecil. Acaravci (2015) menemukan ukuran perusahaan berpengaruh negatif terhadap struktur modal. Dimana perusahaan besar lebih cenderung memilih menggunakan modal untuk membiayai operasionalnya daripada menggunakan hutang. Dengan menurunnya hutang perusahaan memberikan sinyal positif terhadap nilai perusahaan. Hipotesis ini didukung oleh Sri Hermuningsih (2012).

H12: Capital structure diduga mampu memediasi pengaruh firm size terhadap firm value

Efek mediasi capital structure pada growth sales terhadap firm value

Perusahaan dengan pertumbuhan tinggi mengindikasikan aktivitas penjualan yang dilakukan meningkat dari periode sebelumnya, dengan semakin meningkatnya pertumbuhan penjualan berdampak terhadap meningkatnya laba perusahaan yang dihasilkan, dengan peningkatan laba yang dihasilkan berpengaruh pada peningkatan kas perusahaan pada periode mendatang, sehingga penerbitan hutang semakin berkurang hal ini sesuai terhadap teori pecking order (Saidi, 2002). Tingkat hutang yang berkurang akan memberikan sinyal yang baik kepada nilai perusahaan sehingga investor berlomba lomba berinvestasi saham pada perusahaan tersebut.

H13: Struktur modal diduga mampu memediasi pengaruh pertumbuhan perusahaan terhadap nilai perusahaan

\section{METODE PENELITIAN Populasi dan Sampel}

Jumlah populasi per tahun 2017 terdapat 150 Perusahaan Manufaktur yang terdaftar di Bursa Efek Indonesia. Sampel dalam penelitian dipilih dengan metode purposive sampling yang ditunjukkan pada Tabel 1. Berdasarkan kriteria terdapat 27 perusahaan sebagai sampel dalam penelitian ini dengan tahun observasi 2013-2017 (5 tahun) sehingga menghasilkan 135 pengamatan. 
Tabel 1. Penentuan Sampel

\begin{tabular}{clc}
\hline No & \multicolumn{1}{c}{ Keterangan } & Jumlah \\
\hline 1 & Jumlah perusahaan manufaktur yang telah terdaftar di BEI & 150 \\
2 & berturut-turut sejak tahun 2013-2017 & $(72)$ \\
3 & Jumlah perusahaan manufaktur di BEI yang ROA bernilai negatif & $(43)$ \\
4 & bernilai nerusahaan manufakt & $(8)$ \\
& Jumlah Perusahaan yang data variabelnya tidak lengkap & 27 \\
\hline
\end{tabular}

\section{Variabel Dependen}

Nilai perusahaan sebagai variabel terikat dalam penelitian ini yang dipengaruhi oleh beberapa faktor. Nilai perusahaan merupakan nilai atas keberhasilan suatu perusahaan menghasilkan kinerja yang baik dan juga sebagai indikator kemampuan perusahaan memberikan kemakmuran bagi pemegang saham. Semakin tingginya PBV menggambarkan harga saham yang tinggi dibandingkan nilai buku per lembar saham (Robert, 1997).

\section{Variabel Intervening atau Mediasi}

Variabel intervening atau mediasi dalam penelitian ini adalah struktur modal. Struktur modal dalam penelitian ini mengacu pada penelitian Rajni Sofat dan Sukhdev Singh (2017) menggunakan indikator Debt Equity Ratio (DER) yang membagi total kewajiban (liability) dengan total modal (equity).

\section{Variabel Independen}

Variabel independen yang digunakan dalam penelitian ini meliputi :

a. Kepemilikan institusional

Nuraina (2012) mendefinisikan kepemilikan oleh institusi yakni keaktifan pihak pemegang saham yang berasal dari perusahaan sebagai pemilik bagian saham perusahaan. Kepemilikan institusi / perusahaan / lembaga dapat berupa perusahaan yang masih menjadi satu group maupun perusahaan lain yang berpartisipasi dalam pengambilan keputusan perusahaan.

b. Profitabilitas

Pada penelitian ini menggunakan profitabilitas dirumuskan dengan menggunakan kinerja ROA (Return On Total Asset) dimana rasio ini menghasilkan laba bersih perusahaan berdasarkan tingkat asset tertentu suatu perusahaan (Hermawan dan Maf'ulah, 2014).

c. Ukuran Perusahaan

Ukuran perusahaan dapat dinyatakan dari ukuran ekuitas, penjualan atau aset perusahaan. Perusahaan yang besar memiliki bargaining power (kekuatan tawar menawar) yang besar di pasar saham dalam sumber alternatif pendanaan. Proksi ukuran perusahaan dalam penelitian ini adalah logaritma natural dari total aset (David J Smith dkk, 2010).

d. Pertumbuhan Penjualan

Pertumbuhan penjualan merupakan selisih dari total penjualan perusahaan periode saat ini ( $\mathrm{t}$ ) dengan total penjualan tahun lalu ( $\mathrm{t}-1)$ terhadap penjualan periode yang lalu (t-1). Presentase tingkat pertumbuhan ini juga digunakan oleh penelitian sebelumnya (Asifa Kausar dkk, 2014).

\section{Teknik Analisis Data}

Untuk menguji hipotesis menggunakan analisis regresi. Model penelitian yang akan 
digunakan dalam penelitian ini adalah sebagai berikut:

Model 1:

$\mathrm{SM}=\alpha+\beta 1 \cdot \mathrm{KI}+\beta 2 \cdot \mathrm{PR}+\beta 3 \cdot \mathrm{UK}+\beta 4 \cdot \mathrm{PP}+\varepsilon$

Model 2

$\mathrm{NP}=\alpha+\beta 5 . \mathrm{KI}+\beta 6 . \mathrm{PR}+\beta 7 . \mathrm{UK}+\beta 8 . \mathrm{PP}+$ $\beta 9 . S M+\varepsilon$

Keterangan:

KI : Kepemilikan Institusional

PR : Profitabilitas

UK : Ukuran perusahaan

PP : Pertumbuhan penjualan

SM : Struktur modal

NP : Nilai Perusahaan

$\alpha \quad$ : Konstanta

$\beta 1-\beta 9$ : Koefisien regresi

$\varepsilon \quad$ : variabel residual

\section{HASIL DAN PEMBAHASAN}

Analisis Statistik Deskriptif

Perhitungan analisis statistik deskriptif memberikan hasil dari variabel penelitian ditunjukkan pada Tabel 2.

\section{Uji Asumsi Klasik}

Pada model regresi linier berganda, harus dipenuhinya asumsi-asumsi agar kesimpulan yang diambil tidak bias. Deteksi penyimpangan atas asumsi klasik yang perlu untuk diuji adalah normalitas, multikoliniearitas, heteroskedastisitas dan autokorelasi. Hasil uji normalitas awal memberikan hasil bahwa residual tidak terdistribusi normal. Oleh karena itu dilakukan transformasi data (DER dan PBV ditransformasi menjadi Ln) dan identifikasi outlier. Setelah dilakukan koreksi, hasil uji normalitas menunjukkan bahwa uji normalitas terpenuhi. Deteksi terhadap tidak dipenuhinya asumsi klasik dilakukan dengan bantuan software SPSS.

\section{Uji Koefisien Determinasi (Uji R²)}

Besaran pengaruh variabel independen terhadap variabel dependen dapat dijelaskan melalui ukuran berupa koefisien determinasi $\left(\mathrm{R}^{2}\right)$. Nilai $\mathrm{R}^{2}$ semakin tinggi menunjukkan besarnya proporsi pengaruh total variabel dependen yang dijelaskan oleh variabel independen (Ghozali, 2013), hasil perhitngan dapat dilihat pada Tabel 3

Tabel 2. Statistik Deskriptif Variabel Penelitian

\begin{tabular}{lrrrrr}
\hline \multicolumn{5}{c}{ Descriptive Statistics } \\
\hline OWN & $\mathrm{N}$ & \multicolumn{1}{c}{ Min } & \multicolumn{1}{c}{ Max } & \multicolumn{1}{c}{ Mean } & \multicolumn{1}{c}{ Std. Deviasi } \\
ROA & 135 & .06 & 96.09 & 54.51 & 31.47 \\
SIZE & 135 & .20 & 43.93 & 10.28 & 9.19 \\
GRW & 135 & 12.62 & 18.40 & 15.63 & 1.61 \\
DER & 135 & .20 & 90.06 & 14.31 & 13.68 \\
PBV & 135 & .19 & 1134.31 & 88.63 & 155.47 \\
\hline
\end{tabular}

Tabel 3. Hasil Uji Koefisien Determinasi

\begin{tabular}{lllr}
\hline & Model & R Square & \multicolumn{2}{c}{ Adjusted R ${ }^{2}$} \\
\hline Model 1 & & .519 & .503 \\
Model 2 & .604 & .587 \\
\hline
\end{tabular}




\section{Hasil Uji Simultan ( Uji Statistik F )}

Pengujian dilakukan bertujuan untuk melihat pengaruh keseluruhan variabel independen terhadap variabel dependen. Dari hasil pengujian dengan nilai $\mathrm{F}$ ditunjukkan pada Tabel 4. Tabel 4 memberikan hasil nilai $\mathrm{F}$ hitung sebesar 31.076 dan 34.788, dengan nilai probabilitas adalah $0.000<0.05$. Hal ini menunjukkan bahwa secara bersama-sama variabel independen berpengaruh terhadap variabel dependen.

\section{Uji Signifikansi Parameter Individual (Uji} t)

Uji t adalah uji statistik yang diterapkan untuk mengetahui pengaruh dari variabel independen terhadap variabel dependen secara parsial atau terpisah. Berikut merupakan hasil uji t yang dilakukan pada model penelitian 1 dan 2 ditunjukkan pada Tabel 5 dan Tabel 6.

Tabel 4. Hasil Uji Simultan (Uji F)

\begin{tabular}{lrrr}
\hline & Model & F & Sig. \\
\hline Model 1 & 31.076 & $.000^{\mathrm{b}}$ \\
Model 2 & 34.788 & $.000^{\mathrm{b}}$ \\
\hline
\end{tabular}

Tabel 5. Hasil Uji Signifikansi Parameter Individual (Uji t) Model 1

\begin{tabular}{lrrrrr}
\hline & \multicolumn{4}{c}{ Standardized } \\
Model & \multicolumn{2}{c}{ Unstandardized Coefficients } & \multicolumn{2}{c}{ Coefficients } & \multirow{2}{*}{ Sig. } \\
\cline { 2 - 5 } & \multicolumn{2}{c}{ Std. Error } & \multicolumn{2}{c}{ Beta } & .000 \\
(Constant) & 8.450 & 1.105 & & -.230 & .001 \\
OWN & -.011 & .003 & .017 & -.676 & .000 \\
ROA & -.169 & .065 & -.213 & .002 \\
SIZE & -.204 & .010 & .120 & .069 \\
GRW & .019 & &
\end{tabular}

Tabel 6. Hasil Uji Signifikansi Parameter Individual (Uji t) Model 2

\begin{tabular}{lrrrrr}
\hline \multirow{2}{*}{ Model } & \multicolumn{2}{c}{ Unstandardized Coefficients } & \multicolumn{2}{c}{$\begin{array}{c}\text { Standardized } \\
\text { Coefficients }\end{array}$} & \multirow{2}{*}{ Sig. } \\
\cline { 2 - 4 } & \multicolumn{1}{c}{ B } & \multicolumn{2}{c}{ Std. Error } & Beta & \\
\hline (Constant) & -4.648 & .629 & & .091 & .000 \\
OWN & .003 & .002 & .013 & .000 \\
ROA & .107 & .013 & .687 & .000 \\
SIZE & .314 & .039 & .171 & .006 \\
GRW & .017 & .006 & -.224 & .010 \\
Unstandardized & -.686 & .261 & & \\
Predicted Value & & & & \\
\hline
\end{tabular}


Analisis Variabel Mediasi Struktur Modal (Uji Sobel)

Uji Sobel adalah uji statistik yang diterapkan untuk mengetahui pengaruh mediasi hubungan variabel independen terhadap variabel dependen. Berikut merupakan hasil uji Sobel yang dilakukan ditunjukkan pada Tabel 7.

Tabel 7. Hasil Uji Sobel

\begin{tabular}{ccc}
\hline Mediasi & Nilai p-Value & Keterangan \\
\hline OWN $\rightarrow$ SM $\rightarrow$ NP & 0.0326 & Memediasi \\
ROA $\rightarrow$ SM $\rightarrow$ NP & 0.0110 & Memediasi \\
SIZE $\rightarrow$ SM $\rightarrow$ NP & 0.0438 & Memediasi \\
GRW $\rightarrow$ SM $\rightarrow$ NP & 0.1236 & Tidak Memediasi \\
\hline
\end{tabular}

Tabel 8. Hasil Pengujian Hipotesis

\begin{tabular}{ccc}
\hline Hipotesis & Hasil Pengujian & Kesimpulan \\
\hline H1 & $\begin{array}{c}\text { Kepemilikan institusional berpengaruh } \\
\text { negatif dan signifikan terhadap DER } \\
\text { Profitabilitas berpengaruh negatif dan } \\
\text { signifikan terhadap DER }\end{array}$ & H1 diterima \\
H2 & $\begin{array}{c}\text { Ukuran perusahaan berpengaruh negatif } \\
\text { dan signifikan terhadap DER }\end{array}$ & H3 diterima \\
H3 & $\begin{array}{c}\text { Pertumbuhan penjualan berpengaruh positif } \\
\text { tidak signifikan terhadap DER } \\
\text { Kepemilikan institusional berpengaruh } \\
\text { positif tidak signifikan terhadap PBV } \\
\text { Profitabilitas berpengaruh positif dan } \\
\text { signifikan terhadap PBV }\end{array}$ & H4 ditolak \\
H6 & $\begin{array}{c}\text { Ukuran perusahaan berpengaruh positif dan } \\
\text { signifikan terhadap PBV }\end{array}$ & H6 diterima \\
H7 & $\begin{array}{c}\text { Pertumbuhan penjualan berpengaruh } \\
\text { positif dan signifikan terhadap PBV }\end{array}$ & H8 diterima \\
H8 & $\begin{array}{c}\text { Struktur modal berpengaruh negatif dan } \\
\text { signifikan terhadap PBV }\end{array}$ & H9 diterima \\
H9 & $\begin{array}{c}\text { Struktur modal memediasi pengaruh } \\
\text { kepemilikan institusional terhadap PBV } \\
\text { Struktur modal memediasi pengaruh } \\
\text { profitabilitas terhadap PBV }\end{array}$ & H10 diterima \\
H10 & $\begin{array}{c}\text { Struktur modal memediasi pengaruh } \\
\text { ukuran perusahaan terhadap PBV } \\
\text { H11 }\end{array}$ & H11 diterima \\
H12 & $\begin{array}{c}\text { Struktur modal tidak memediasi pengaruh } \\
\text { pertumbuhan penjualan terhadap PBV }\end{array}$ & H12 diterima \\
H13 & \begin{tabular}{c} 
Hitolak \\
\hline
\end{tabular} & \\
\hline
\end{tabular}


Pengaruh kepemilikan institusional terhadap struktur modal (Hipotesis 1).

Dalam hipotesis $1\left(\mathrm{H}_{1}\right)$ menyatakan kepemilikan institusional berpengaruh negatif terhadap capital structure. Hasil pengujian hipotesis kepemilikan institusional memiliki arah negatif signifikan yang berarti kepemilikan institusional berpengaruh negatif dan signifikan terhadap struktur modal. Semakin tinggi ataupun rendah kepemilikan institusional suatu perusahaan manufaktur di BEI mempengaruhi besar kecilnya rasio struktur modal yang di tetapkan oleh suatu perusahaan yang bersangkutan ( $\mathbf{H}_{\mathbf{1}}$ diterima) .

Hal ini mengindikasikan bahwa adanya kepemilikan institusional mampu menghasilkan pengaruh signifikan dalam mengambil keputusan pendanaan. Kepemilikan institusional sebagai suatu mekanisme eksternal tata kelola perusahaan dianggap mampu untuk memberikan pengaruh secara maksimal dalam upaya pengawasan dan pengurangan konflik keagenan. Dengan adanya pengawasan oleh pihak institusional membuat manajer lebih alert dalam membuat keputusan kebijakan pendanaan, sehingga hutang yang digunakan dapat ditekan seminimal mungkin (Jensen dkk, 1992).

Penelitian ini memberikan hasil yang sejalan dengan penelitian Chune Young Chung dan Kainan Wang (2018) yang mengatakan bahwa institutional ownership berpengaruh negatif terhadap struktur modal.

Pengaruh profitability terhadap capital structure (Hipotesis 2).

Dalam hipotesis $2\left(\mathrm{H}_{2}\right)$ menyatakan profitability berpengaruh negatif terhadap capital structure. Hasil pengujian hipotesis menyatakan profitabilitas berpengaruh negatif dan signifikan. Hal ini variabel profitabilitas berpengaruh negatif terhadap struktur modal. Perusahaan yang memiliki profitabilitas semakin tinggi akan memberikan rasio struktur modal semakin kecil sebaliknya profitabilitas suatu perusahaan semakin rendah memberikan rasio struktur modal semakin tinggi $\left(\mathbf{H}_{2}\right.$ diterima). Hal ini sesuai dengan teori pecking order memaparkan perusahaan memprioritaskan penggunaan sumber daya internal sebagai sumber pendanaan perusahaan dibandingkan memutuskan berhutang.

Profitabilitas yang dihasilkan perusahaan mencerminkan kemampuan perusahaan dalam penggunaan seluruh aktivanya secara produktif. Rasio laba yang dihasilkan oleh perusahaan merupakan cerminan dari profitabilitas. Tingkat keuntungan perusahaan atau yang lebih dikenal dengan rasio profitabilitas adalah nominal laba bersih yang dihasilkan perusahaan dari aktivitas penjualan, kepemilikan aset serta modal yang mereka miliki (Wulandari, 2010). Kondisi keuangan dalam menghasilkan laba bersih suatu perusahaan membuat kebutuhan perusahaan akan pendanaan cukup menggunakan dana internal.

Penelitian ini sejalan pada penelitian Purwohandoko (2017); Basil Al Najjar dan Khaled Husainney (2011); Nadeem Ahmed Sheikh dan Zongjun Wang (2013); Rajni Sofat dan Sukhdev Singh (2017); Ramazan Yildirima, dkk (2018); Larry Li dan Silvia Z (2018); Tharmalingam Pratheepan dan Y.K.Weerakoon Banda (2016); Mohammad Alipour, dkk (2017) yang membuktikan bahwa profitability berpengaruh negatif terhadap capital structure.

\section{Pengaruh ukuran perusahaan terhadap struktur modal (Hipotesis 3).}

Dalam hipotesis $3\left(\mathrm{H}_{3}\right)$ menyatakan ukuran perusahaan berpengaruh negatif terhadap struktur modal. Hasil pengujian 
hipotesis dengan ukuran perusahaan berpengaruh negatif dan signifikan. Hal ini menunjukkan ukuran perusahaan berpengaruh negatif dan signifikan terhadap struktur modal. Semakin besar maupun kecil ukuran suatu perusahaan manufaktur di BEI mempengaruhi besar kecilnya rasio struktur modal yang di tetapkan oleh suatu perusahaan yang bersangkutan (H3 diterima).

Perusahaan yang memiliki kekuatan finansial dan apakah mendapatkan kepercayaan dimata investor menjelaskan pengaruh ukuran perusahaan, yang menyatakan perusahaan berukuran besar seharusnya mampu mendanai operasional perusahaan dengan biaya sendiri karena memiliki laba dan asset yang besar (Soliha dan Taswan, 2002).

Sesuai teori pecking order perusahaan yang berukuran besar lebih memilih menggunakan sumber dana internal (ekuitas) untuk membiayai operasionalnya daripada menggunakan sumber dana eksternal (hutang). Perusahaan besar identik mempunyai aset yang lebih besar berpeluang untuk menghasilkan pendapatan yang besar sehingga akan cenderung menggunakan laba perusahaan untuk diinvestasikan kembali. Perusahaan besar akan membutuhkan lebih sedikit dana eksternal berupa hutang dari pada perusahaan kecil. Acaravci (2015) menemukan ukuran perusahaan berpengaruh negatif terhadap struktur modal. Dimana perusahaan besar lebih cenderung memilih menggunakan modal internal untuk membiayai operasionalnya daripada menggunakan hutang.

Penelitian ini sejalan dengan penelitian Elva Nuraina (2012) dan Mohammad Alipour, dkk (2017) yang mengatakan bahwa ukuran perusahaan berpengaruh negatif terhadap struktur modal.

\section{Pengaruh pertumbuhan perusahaan terhadap struktur modal (Hipotesis 4).}

Dalam hipotesis $4\left(\mathrm{H}_{4}\right)$ menyatakan pertumbuhan perusahaan berpengaruh negatif terhadap struktur modal. Hasil pengujian hipotesis yaitu pertumbuhan perusahaan memiliki berpengaruh positif dan tidak signifikan. Hal ini berarti pertumbuhan perusahaan berpengaruh positif tidak signifikan terhadap struktur modal. Semakin besar maupun kecil pertumbuhan perusahaan manufaktur di BEI tidak mempengaruhi besar kecilnya rasio struktur modal yang di tetapkan oleh suatu perusahaan yang bersangkutan ( $\mathbf{H}_{\mathbf{4}}$ ditolak).

Menurut Eriotis (2007) semakin meningkatnya pertumbuhan penjualan memberikan pengaruh terhadap sumber dana internal yang tersedia untuk operasional perusahaan, hal ini mengindikasikan adanya kecenderungan perusahaan untuk memanfaatkan pertumbuhan penjualannya dengan meningkatkan operasionalnya. Peningkatan operasional perusahaan berarti bertambahnya beban operasional tambahan bagi operasional tersebut, dan karenanya perusahaan kemudian akan menetapkan kebijakan pengaturan struktur modal dalam rangka mendukung kegiatan operasionalnya, hal ini sesuai dengan teori pecking order menyatakan perusahaan akan memilih pendanaan bersumber dari dana internal (retain earning dan diinvestasikan kembali) daripada pendanaan dari luar perusahaan. Urutan pendanaan eksternal yang diputuskan perusahaan yaitu dengan hutang pilihan utama kemudian menerbitkan saham baru merupakan pilihan terakhir. Hutang yang diterbitkan perusahaan sesuai akan kebutuhannya pada pendanaan eksternal.

Hasil penelitian ini tidak sesuai dengan penelitian Mohammad Javad Shyekh, dkk (2017); Mohammad Alipour, dkk (2017) yang 
mengatakan bahwa pertumbuhan penjualan berpengaruh negatif terhadap struktur modal.

\section{Pengaruh kepemilikan institusional} terhadap nilai perusahaan (Hipotesis 5).

Dalam hipotesis $5\left(\mathrm{H}_{5}\right)$ menyatakan kepemilikan institusional berpengaruh positif terhadap nilai perusahaan. Hasil pengujian kepemilikan institusional berpengaruh positif tidak signifikan. Hal ini berarti kepemilikan institusional berpengaruh positif tetapi tidak signifikan terhadap nilai perusahaan. Tinggi rendahnya kepemilikan institusional suatu perusahaan manufaktur di BEI tidak dapat meningkatkan ataupun menurunkan nilai perusahaan tersebut ( $\mathbf{H}_{5}$ ditolak).

Menurut Jensen (1986) dengan kepemilikan institusional yang tinggi dapat mengurangi konflik keagenan karena pihak institusional bertindak melakukan pengawasan yang ketat terhadap manajemen perusahaan, yang membuat manajer akan efisien dalam penggunaan aset perusahaan. Akan tetapi, hasil penelitian ini pengaruh positif tersebut tidak signifikan.

Hal ini mengindikasikan bahwa adanya kepemilikan institusional belum mampu menghasilkan pengaruh signifikan terhadap nilai perusahaan. Kepemilikan institusional sebagai suatu mekanisme eksternal tata kelola perusahaan belum dianggap mampu untuk memberikan pengaruh secara maksimal dalam upaya pengawasan dan pengurangan konflik keagenan. Hal yang mungkin dapat dijelaskan adalah sebagian besar kepemilikan institusional perusahaan bersifat terkonsentrasi pada satu atau lebih perusahaan, sehingga fungsi dari pengawasan terhadap kinerja manajemen tidak optimal, sehingga hasil penelitian ini tidak sesuai dengan agency theory.

Penelitian ini memberikan hasil yang bertolak belakang terhadap penelitian Ngatemin, dkk (2018); Johny Budiman
(2015); Elva Nuraina (2012); Rakesh Mishra dan Sheeba Kapil (2017); Yongjia Rebecca Lin dan Xiaoqing Maggie $\mathrm{Fu}$ (2017) yang membuktikan bahwa kepemilikan institusional berpengaruh positif terhadap nilai perusahaan.

\section{Pengaruh profitabilitas terhadap nilai perusahaan (Hipotesis 6).}

Dalam hipotesis $6\left(\mathrm{H}_{6}\right)$ menyatakan profitabilitas berpengaruh positif terhadap nilai perusahaan. Hasil penelitian profitabilitas berpengaruh positif dan signifikan. Profitabilitas berpengaruh positif terhadap nilai perusahaan. Semakin tinggi tingkat profitabilitas suatu perusahaan memberikan hasil nilai perusahaan yang semakin besar begitu juga sebaliknya (H6 diterima).

Perusahaan yang memiliki profit tinggi memberikan sinyal positif kepada investor. Sudiyatno (2010) dan Uchida (2006) membuktikan adanya pengaruh positif profitabilitas terhadap nilai perusahaan. Peningkatan profitabilitas mengindikasikan bahwa prospek perusahaan cukup baik, yang berimplikasi dengan meningkatnya nilai perusahaan karena adanya respon positif dari investor yang berlomba-lomba membeli saham di perusahaan tersebut.

Penelitian Ngatemin, dkk (2018); Muhammad Thamrin, H. Rahman Mus, Sudirman dan Aryati Arfah (2017); Ayu Sri dan Ary Wirajaya (2013); Aldea Mita Cheryta, Moeljadi dan Nur Khusniyah Indrawati (2017); Yuanita Missy, Budiyanto dan Slamet Riyadi (2016); Ben Said Hatem (2015); Divya Anngarwal dan Purna Chandra Padhan (2017); Hariandy Hasbi (2015) sejalan dengan hasil penelitian ini bahwa profitabilitas berpengaruh positif terhadap nilai perusahaan.

Pengaruh ukuran perusahaan terhadap nilai perusahaan (Hipotesis 7). 
Dalam hipotesis $7\left(\mathrm{H}_{7}\right)$ menyatakan ukuran perusahaan berpengaruh positif terhadap nilai perusahaan. Hasil penelitian ukuran perusahaan berpengaruh positif dan signifikan. Hal ini berarti ukuran perusahaan berpengaruh positif dan signifikan terhadap nilai perusahaan. Semakin tinggi ukuran perusahaan maka semakin besar nilai perusahaan begitu juga sebaliknya $\mathbf{C H}_{\mathbf{7}}$ diterima).

Perusahaan besar memberikan sinyal positif yang mencerminkan bahwa dengan semakin besarnya perusahaan diharapkan memberikan laba bersih yang lebih besar sehingga perusahaan akan memberikan lebih besar deviden dibandingkan dengan perusahaan kecil. Berdasarkan signaling theory bahwa perusahaan yang semakin besar mencerminkan perkembangan bisnis perusahaan, kondisi yang stabil serta tingkat return investor lebih tinggi, hal ini dapat memberikan sinyal positif oleh investor berimplikasi pada harga saham ikut meningkat sehingga nilai perusahaan juga akan meningkat.

Penelitian ini konsisten pada penelitian Ben Said Hatem (2015); Yuanita Missy, Budiyanto dan Slamet Riyadi (2016) dan Siahaan (2013) ; Elva Nuraina (2012); Nadeem Ahmed Sheikh dan Zongjun Wang (2013); Divya Anngarwal dan Purna Chandra Padhan (2017) yang mengatakan bahwa ukuran perusahaan berpengaruh positif terhadap nilai perusahaan.

\section{Pengaruh pertumbuhan penjualan} terhadap nilai perusahaan (Hipotesis 8).

Dalam hipotesis $8\left(\mathrm{H}_{8}\right)$ menyatakan pertumbuhan perusahan yang diukur dengan pertumbuhan penjualan berpengaruh positif terhadap nilai perusahaan. Hasil penelitian pertumbuhan perusahaan berpengaruh positif dan signifikan. Hal ini berarti pertumbuhan penjualan berpengaruh terhadap nilai perusahaan. Tinggi rendahnya nilai pertumbuhan penjualan suatu perusahaan manufaktur di BEI dapat meningkatkan ataupun menurunkan nilai perusahaan tersebut (H8 diterima).

Abundanti (2012) menyatakan pertumbuhan perusahaan dapat menjadi indikator nilai perusahaan. Dari perspektif investor, pertumbuhan perusahaan menunjukkan sinyal positif dan baik perkembangan dimana pertumbuhan suatu perusahaan yang memiliki dampak yang menguntungkan dan perusahaan juga mengharapkan tingkat pengembalian investasi yang dilakukan.

Penelitian Nadeem Ahmed Sheikh dan Zongjun Wang (2013); Thi Phuong Vy Le dan Thi Bich Nguyet Phan (2017) sejalan dengan hasil penelitian ini yang mengatakan bahwa pertumbuhan penjualan berpengaruh positif terhadap nilai perusahaan.

\section{Pengaruh struktur modal terhadap nilai perusahaan (Hipotesis 9).}

Dalam hipotesis $9(\mathrm{H} 9)$ menyatakan struktur modal berpengaruh negatif terhadap nilai perusahaan. Hasil penelitian menunjukkan struktur modal berpengaruh negatif dan signifikan terhadap nilai perusahaan. Rasio struktur modal suatu perusahaan yang semakin besar memberikan pengaruh semakin kecil nilai perusahaan pada batasan di atas titik optimalnya begitu juga sebaliknya (Ho diterima).

Hal ini sesuai dengan teori trade off yang menyatakan penggunaan struktur modal yang optimal diikuti dengan menyeimbangkan keuntungan penggunaan hutang terhadap biaya kebangkrutan keuangan dan agency problem. Sebaliknya, hutang tambahan apapun akan menurunkan nilai perusahaan pada kondisi struktur modal berada di atas titik optimal. 
Penelitian ini sejalan terhadap penelitian Nadeem Ahmed Sheikh dan Zongjun Wang (2013); Ayu Sri Mahatma Dewi dan Ary Wirajaya (2013); Siahaan (2013); Rakesh Mishra dan Sheeba Kapil (2017); Thi Phuong Vy Le dan Thi Bich Nguyet Phan (2017); Asifa Kausar, dkk (2014) yang mengungkapkan bahwa struktur modal berpengaruh negatif terhadap nilai perusahaan.

\section{Pengaruh kepemilikan institusional terhadap nilai perusahaan melaluhi struktur modal (Hipotesis 10).}

Dalam hipotesis $10\left(\mathrm{H}_{10}\right)$ menyatakan struktur modal memediasi pengaruh kepemilikan institusional terhadap nilai perusahaan. Hasil penelitian menunjukkan memediasi hubungan antara kepemilikan institusional terhadap nilai perusahaan. Semakin tinggi ataupun rendah rasio struktur modal mampu memediasi hubungan antara kepemilikan institusional terhadap nilai perusahaan (H10 diterima).

Teori agensi dimana saham pihak institusional yang besar maka konflik keagenan dapat diturunkan dengan melakukan pengawasan agen terkait kebijakan manajemen struktur modal. Dengan pengawasan yang dilakukan pihak institusional maka manajer akan lebih prudensial pada setiap kebijakannya terutama kebijakan hutang, sehingga penerbitan hutang yang dilakukan menjadi rendah (Jensen dkk, 1992). Peningkatan hutang perusahaan memiliki sinyal negatif kepada investor. Struktur modal dapat menurunkan nilai perusahaan menunjukkan sinyal negatif (Ang, 1997).

Hasil penelitian ini sesuai dengan penelitian Johny Budiman (2015) yang mengungkapkan bahwa struktur modal memediasi pengaruh kepemilikan institusional berpengaruh positif terhadap nilai perusahaan.

Pengaruh profitabilitas terhadap nilai perusahaan melaluhi struktur modal (Hipotesis 11).

Dalam hipotesis $11\left(\mathrm{H}_{11}\right)$ menyatakan struktur modal memediasi pengaruh profitabilitas terhadap nilai perusahaan. Hasil penelitian menunjukkan memediasi hubungan antara profitabilitas terhadap nilai perusahaan (H11 diterima).

Laba ditahan yang diperoleh menyebabkan perusahaan tersebut tidak membutuhkan dana eksternal untuk menunjang operasionalnya karena dengan laba ditahan yang diperoleh membuat perusahaan dapat mendanai dengan dana internal. Perusahaan yang dapat mendanai dengan dana internal akan membuat perusahaan lebih baik dengan cara laba yang ditahan dan diinvestasikan kembali. Perusahaan yang memperoleh hutang akan memberikan sinyal negatif berdampak pada harga saham, hal ini berkaitan dalam pembayaran kewajiban perusahaan apabila besar rasio debt yang digunakan untuk struktur modal semakin besar (Ang, 1997 dan Kraft dkk, 2013).

Penelitian struktur modal memediasi pengaruh profitabilitas berpengaruh positif terhadap nilai perusahaan sejalan dengan penelitian Johny Budiman (2015) dan Sri Hermuningsih (2012).

\section{Pengaruh Ukuran Perusahaan terhadap Nilai Perusahaan melaluhi Struktur Modal (Hipotesis 12).}

Dalam hipotesis $12\left(\mathrm{H}_{12}\right)$ menyatakan struktur modal memediasi pengaruh ukuran perusahaan terhadap nilai perusahaan. Hasil penelitian menunjukkan memediasi hubungan antara ukuran perusahaan terhadap nilai perusahaan. Semakin tinggi 
ataupun rendah rasio struktur modal mampu memediasi hubungan antara ukuran perusahaan terhadap nilai perusahaan (H12 diterima).

Perusahaan besar memiliki asset yang lebih besar berpeluang untuk menghasilkan pendapatan yang besar sehingga akan cenderung menggunakan laba perusahaan untuk diinvestasikan kembali. Perusahaan besar akan membutuhkan lebih sedikit dana eksternal berupa hutang dari pada perusahaan kecil.

Penelitian ini konsisten dengan penelitian Sri Hermuningsih (2012) yang membuktikan bahwa struktur modal memediasi pengaruh ukuran perusahaan berpengaruh terhadap nilai perusahaan.

\section{Pengaruh pertumbuhan penjualan terhadap nilai perusahaan melaluhi struktur modal (Hipotesis 13).}

Dalam hipotesis $13\left(\mathrm{H}_{13}\right)$ menyatakan struktur modal memediasi pengaruh pertumbuhan perusahaan terhadap nilai perusahaan. Hasil penelitian menunjukkan tidak memediasi hubungan antara pertumbuhan perusahaan terhadap nilai perusahaan. Semakin tinggi ataupun rendah rasio struktur modal tidak mampu memediasi hubungan antara pertumbuhan penjualan terhadap nilai perusahaan (H13 ditolak).

Penelitian ini memberikan hasil tidak ada pengaruh langsung pertumbuhan perusahaan terhadap DER. Hal tersebut menunjukkan bahwa pertumbuhan perusahaan tidak mempengaruhi DER, sehingga DER tidak dapat memediasi untuk meningkatkan nilai perusahaan. Mengacu terhadap konsep mediasi ditemukan oleh Sarwono (2010) yang menyatakan bahwa mediasi oleh variabel intervening hanya dapat terjadi manakala variabel bebas dari sebuah penelitian berpengaruh secara signifikan terhadap variabel intervening serta variabel intervening terbukti berpengaruh signifikan terhadap variabel terikat, maka tidak berpengaruhnya variabel bebas pertumbuhan perusahaan terhadap variabel intervening DER menyebabkan jalur mediasi terputus.

\section{KESIMPULAN DAN IMPLIKASI KEBIJAKAN}

Hasil penelitian bahwa kepemilikian institusional, profitabilitas dan ukuran perusahaan berpengaruh negatif dan signifikan terhadap struktur modal. Pertumbuhan penjualan berpengaruh positif dan tidak signifikan terhadap struktur modal. Kepemilikan institusional tidak berpengaruh secara signifikan terhadap nilai perusahaan. Profitabilitas, ukuran perusahaan dan pertumbuhan penjualan berpengaruh positif dan signifikan terhadap nilai perusahaan. Struktur modal berpengaruh negatif dan signifikan terhadap nilai perusahaan. Struktur modal memediasi hubungan kepemilikan institusional, profitabilitas dan ukuran perusahan terhadap nilai perusahaan. Struktur modal tidak memediasi hubungan pertumbuhan penjualan terhadap nilai perusahaan.

Variabel-variabel independen yang dipakai untuk mengetahui variasi DER dalam penelitian ini masih terbatas. Hal ini dapat diketahui dari nilai Adjusted $\mathrm{R}^{2}$ Model 1 yang besarnya 50.3\% dan nilai Adjusted $\mathrm{R}^{2}$ Model 2 (model penelitian dengan variabel intervening) yang besarnya 58.7\%. Nilai Adjusted $\mathrm{R}^{2}$ tersebut dapat dikatakan masih rendah. Artinya, masih terdapat variabelvariabel lain yang dapat memiliki pengaruh signifikan terhadap PBV dan seharusnya dimasukkan ke dalam model penelitian. Mengacu pada hasil ini maka disarankan untuk mencari variabel variabel bebas lain yang dapat dijadikan sebagai variabel bebas terhadap PBV contohnya tangibilitas dan 
likuiditas agar penelitian selanjutnya besaran

Adjusted $\mathrm{R}^{2}$ menjadi lebih baik.

\section{REFERENSI}

Abdul, Masdiah., Abdullah, Azizah \& Atiqah, Nur. 2015. "Struktur modal and Profitabilitas in Family and Non-Family Firms: Malaysian evidence". Procedia Economics and Finance, Vol.31, hal. 44-55

Ahmed, Nadeem \& Wang, Zongjun. 2011. "The Impact of Struktur modal on Performance : an Empirical Study of Non-Financial Listed in Firms Pakistan". International Journal of Commerce and Management, Vol. 23, No.4, hal. 354-368

Anggarwal, Divya \& Chandra, Purna. 2017. "Impact of Struktur modal on Nilai perusahaan: Evidence from Indian Hospitality Industry". Scientif Research Publishing, Vol.7, hal. 9821000

Al-Najjar, Basil \& Hussainey, Khaled. 2011. "Revisiting the capital-structure puzzle: UK evidence". The Journal of Risk Finance, Vol.12, No.4, hal. 329-338

Ali, Awais., Qiang, Fu \& Ashraf, Sadia. 2017. "Regional dynamics of ownership structure and their impact on firm performance and firm valuation: a case of Chinese listed companies". Review of International Business and Strategy, hal. 1-21

Alipour, Mohammad., Farhad, Mir \& Derakhshan, Hojjatollah. 2015. "Determinants of struktur modal: an empirical study of firms in Iran". International Journal of Law and Management, Vol. 57, No. 1. hal. 53-83

Budiman, Johny. 2015. "Corporate Governance, Struktur modal and Shareholder Value of Indonesian Stock Exchange Firms". Jurnal Manajemen, Vol.15, No.1, hal. 75-94

Claude, Rusibana. 2016. " Organizational Determinants, Struktur modal and Financial Performance of Firms Registered in Rwanda Development Board". The International Journal Of Business \& Management, Vol.4, No.8, hal. 105-129

Hasbi, Hariandy. 2015. "Islamic Microfinance Institution : The Struktur modal, Growth, Performance and Value of Firm in Indonesia". Procedia Social and Behavioral Sciences, Vol. 211, hal. 1073-1080

Hermuningsih, Sri. 2012. "Pengaruh Profitabilitas, Size terhadap Nilai Perusahaan dengan Struktur Modal sebagai Variabel Intervening”. Jurnal Siasat Bisnis,, Vol.16, No.2, hal. 232-242

Huang, Ziwei. \& Pan, Haiying. 2016. "A Study on the Impact of Struktur modal of China's Listed Commercial Banks on Profitabilitas”. Management \& Engineering, Vol. 22, hal. 1838-5745

Ibrahim, Mahmoud. 2017. "Struktur modal and Nilai perusahaan in Nigerian Listed Manufacturing Companies: an Empirical Investigation Using Tobin's Q Model”. International Journal of Innovative Research in Social Sciences \& Strategic Management Techniques, Vol. 4, No. 2, hal. 112-125 
Jan, Hassan., Khan, Faisal \& Imran, Muhammad. 2016. "Impact of Debt pn Profitabilitas of Firms : Evidence from Non-Financial Sector of Pakistan". City University Research Journal, Vol. 6, No. 1, hal. 70-80

Ju-Chen, Li \& Yu-Chen, Shun. 2011. "The influence of profitabilitas on nilai perusahaan with struktur modal as the mediator and ukuran perusahaan and industry as moderators". Investment Management and Financial Innovations, Vol. 8, No. 3, hal. 121-129

Kausar, Asifa., Sajid, Mian \& Awais, Hashim. 2014. "Struktur modal and Nilai perusahaan: Empirical Evidence from Pakistan". Asian Journal of Research in Economics and Finance, Vol. 1,No. 1, hal. 11-22

Kodongo, Odongo., Makoaleli-Makoteli, Thabang \& Maina, Leonard. 2014. "Struktur modal, profitabilitas and nilai perusahaan: panel evidence of listed firms in Kenya". Munich Personal RePEc Archive, Vol. 57116,No. 6, hal. 1-19

Li, Larry \& Z, Silvia. 2018. "Firm and industry specific determinants of struktur modal: Evidence from the Australian market". International Review of Economics and Finance, hal. 1-13

Mita, Aldea., Moeljadi \& Khusniyah, Nur. 2017. "The Effect of Leverage, Profitabilitas, Information Asymmetry, Ukuran perusahaan on Cash Holding and Nilai perusahaan of Manufacturing Firm Listed at Indonesian Stock Exchange". International Journal of Research in Business Studies and Management, Vol.4, No.4, hal. 21-31

Mishra, Rakesh \& Kapil, Sheeba. 2017. " Effect of ownership structure and board structure on nilai perusahaan: evidence from India". International The International Journal of Business in Society, Vol.17, No.4, hal. 700-726

Missy, Yuanita., Budiyanto \& Riyadi, Slamet. 2016. "Influence of struktur modal, size and growth on profitabilitas and corporate value". International Journal of Business and Finance Management Research, Vol.4, hal. 80-101

Narang, Megha. 2018. " Impact of struktur modal on firm performance: A study of listed firms on national stock exchange". International Journal of Advanced Educational Research, Vol.3, No.1, hal. 251-254

Ngatemin., Maksum, Azhar., Erlina \& Sirojulzilam. 2018. "Effects of Kepemilikan institusional and Profitabilitas to Nilai perusahaan with the Struktur modal as Intervening Variable (Empirical Study at Company Tourism Industry Sector Listed in Indonesia". International Journal of Civil Engineering and Technology (IJCIET), Vol.9, No.5, hal. 1305-1320

Nuraina, Elva. 2012. "Pengaruh Kepemilikan Institusional dan Ukuran Perusahaan terhadap Kebijakan Hutang dan Nilai Perushaan". Jurnal Bisnis dan Ekonomi , Vol. 19, No.2, hal. 110125

Pirzada, Kashan., Zulkhairi, Mohd \& Wickramasinghe, Danture. 2015. "Firm Performance, Kepemilikan institusional and Struktur modal : A Case of Malaysia". Procedia Social and Behavioral Sciences, Vol. 211, hal. 170-176 
Purwohandoko. 2017. "The influence of Firm's Size, Growth, and Profitabilitas on Nilai perusahaan with Struktur modal as the Mediator : A study on the Agricultural Firms Listed in the Indonesian Stock Exchange". International Journal of Economics and Finance, Vol. 9, No. 8, hal. 103-110

Rebecca, Yongjia \& Maggie, Xiaoqing. 2017. "Does kepemilikan institusional influence firm performance? Evidence from China”. International Review of Economics and Finance, Vol.49, hal. 17-57

Said, Ben. 2015. "Interdependence between Managerial Ownership, Leverage and Nilai perusahaan : Theory and Empirical Validation". International Journal of Economics and Finance, Vol. 7, No.12, hal. 106-118

Setiadharma \& Machali. 2017. "The Effect of Asset Structure and Ukuran perusahaan on Nilai perusahaan with Struktur modal as Intervening Variable”. Journal of Business \&Financial Affairs, Vol.6, No.4, hal. 1-5

Siahaan, Fadjar. 2013. "The Effect of Good Corporate Governance Mechanism, Leverage, and Ukuran perusahaan on Nilai perusahaan”. GSTF Journal on Business Review (GBR) , Vol. 2, No.4, hal. 137-142

Sofat, Rajni \& Singh, Sukhdev. 2016. "Determinants of struktur modal: an empirical study of manufacturing firms in India". International Journal of Law and Management, Vol. 59, No.6, hal. 1029-1045

Sri, Ayu \& Wirajaya, Ary. 2013. “Pengaruh Struktur Modal, Profitabilitas dan Ukuran Perusahaan pada Nilai Perusahaan”. E-Jurnal Akuntansi Universitas Undayana, hal 358-372

Syekh, Mohammad Javad., Rezayar, Ali \& Alinejad, Mahmoud. 2017. "Evaluation of Lifecycle and Struktur modal of Listed Automotive Industry in Tehran Stock Exchange". Kuwait Chapter of Arabian Journal of Business and Management Review, Vol.6, No.8, hal. 38-51

Yildirim, Ramazan., Masih, Mansur \& Ismath, Obiyathullah. 2018. "Determinants of struktur modal: evidence from Shari'ah compliant and non-compliant firms". Pacific-Basin Finance Journal, Vol.51, hal. 198-219

Young, Chune., Liu, Chang \& Wang, Kainan. 2018. "Do firms have target struktur modals? Evidence from institutional monitoring". International Review of Economics and Finance, Vol.58, hal. 65-77

Yuanita., Missy., Budiyanto \& Riyadi, Slamet. 2016. "Influence of Struktur modal, Size, and Growth on Profitabilitas and Corporate Value". International Journal of Business and Finance Management Research, Vol.4, hal. 80-101 